Article

\title{
Structural Revision of Wentiquinone $C$ and Related Congeners from Anthraquinones to Xanthones Using Chemical Derivatization and NMR Analysis
}

\author{
Xin $\mathrm{Li}^{1,2}$, Xiao-Ming $\mathrm{Li}^{1,2}$ and Bin-Gui Wang ${ }^{1,2, *(\mathbb{D})}$ \\ 1 Key Laboratory of Experimental Marine Biology, Institute of Oceanology, Chinese Academy of Sciences, \\ Laboratory of Marine Biology and Biotechnology, Pilot National Laboratory for Marine Science and \\ Technology (Qingdao), Nanhai Road 7, Qingdao 266071, China; lixin871014@163.com (X.L.); \\ lixmqdio@126.com (X.-M.L.) \\ 2 Center for Ocean Mega-Science, Chinese Academy of Sciences, Nanhai Road 7, Qingdao 266071, China \\ * Correspondence: wangbg@ms.qdio.ac.cn; Tel.: +86-532-8289-8553
}

Received: 4 December 2018; Accepted: 20 December 2018; Published: 24 December 2018

\begin{abstract}
Wentiquinone $C$, which was previously isolated from the marine brown alga-derived endophytic fungus Aspergillus wentii EN-48, was found to be a potent antioxidant against $\alpha, \alpha$-diphenyl-picrylhydrazyl (DPPH) radical. The structure of wentiquinone $\mathrm{C}$ was originally assigned as an anthraquinone derivative (1,10-dihydroxy-3-(hydroxymethyl)-8-methoxydibenzo $[b, e]$ oxepine-6,11-dione, 1) by $1 \mathrm{D}$ and 2D NMR experiments. However, the minor differences of the chemical shifts between xanthones and anthraquinones were queried, leading to the structure of 1 to be revised as a xanthone analog (8-hydroxy-6-(hydroxymethyl)-3-methoxy-9oxo-9H-xanthene-1-carboxylic acid, 2) on the basis of a methylation and subsequent NMR measurements, and was confirmed by X-ray crystallographic analysis. The method established in this paper could be applied to the structural re-examination or revision for some of the reported seco-anthraquinone derivatives.
\end{abstract}

Keywords: Structure revision; Wentiquinone C; Methylation method; Xanthones; Anthraquinones; Aspergillus wentii

\section{Introduction}

In the course of our chemical investigation of marine-derived fungi for bioactive metabolites, we have isolated and assigned the structure of wentiquinone $C$ as an anthraquinone derivative from the marine brown algal-derived endophytic fungus Aspergillus wentii EN-48, and the compound showed potent antioxidant activity against $\alpha, \alpha$-diphenyl-picrylhydrazyl (DPPH) radicals [1]. Based on the NMR analysis, its structure was originally assigned as 1,10-dihydroxy-3 -(hydroxymethyl)-8- methoxydibenzo[b,e]oxepine-6,11-dione (anthraquinone derivative, 1), which contained a seven-membered lactone ring in the structure (Figure 1). In our continuing investigation for more bioactive secondary metabolites from the same fungal strain, compound $\mathbf{3}$ was characterized, and its ${ }^{1} \mathrm{H}$ and ${ }^{13} \mathrm{C}$ NMR spectral data were very similar to those of wentiquinone $\mathrm{C}$, indicating that $\mathbf{3}$ might be an analog of wentiquinone C. However, the structure of $\mathbf{3}$ was finally assigned to be calyxanthone, a xanthone derivative that was firstly discovered in 1983, according to its NMR data [2]. Compounds 1 and $\mathbf{3}$ have very similar NMR data but belonged to anthraquinone and xanthone derivatives, respectively, and this phenomenon promoted us to query if there is other possible structure assigned for wentiquinone $C(\mathbf{1})$ as a xanthone (2). Meanwhile, Yenesew and co-workers proposed the revision for a group of seco-anthraquinones to xanthones [3], and suggested that the structure of wentiquinone $C$ should also be revised. Nevertheless, it was challenging to distinguish $\mathbf{1}$ and $\mathbf{2}$ 
based only on the MS and NMR data because they possessed the same carbon connectivity, similar NMR chemical shifts, and identical HMBC correlations. To clear up this confusion, a methylation and subsequent NMR analysis were employed successfully, and leading to unambiguously revision of the structure of wentiquinone $C$ from an anthraquinone derivative (1) to a xanthone analogue (2) (Figure 1). This paper details the structure revision of wentiquinone $C$ and other related natural products.<smiles>COc1cc(O)c2c(=O)c3c(O)cc(CO)cc3oc(=O)c2c1</smiles>

wentiquinone $C(1$, originally assigned)

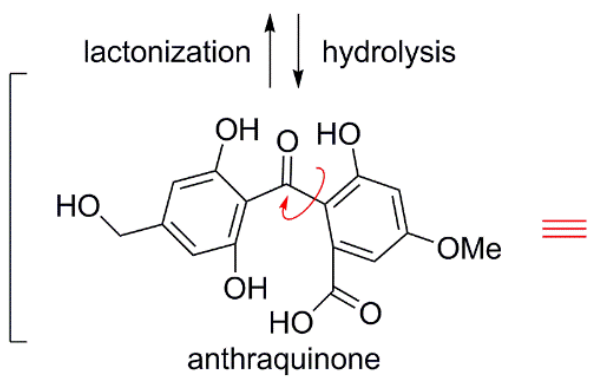<smiles>COc1cc(O)c2c(=O)c3c(O)cc(CO)cc3oc(=O)c2c1</smiles>

wentiquinone $C(\mathbf{1}$, originally assigned) or<smiles>[R]Cc1cc(O)c2c(=O)c3c(C(=O)OC)cc(OC)cc3oc2c1</smiles>

wentiquinone $\mathrm{C}: \mathrm{R}_{1}=\mathrm{OH}, \mathrm{R}_{2}=\mathrm{H}(2$, revised)

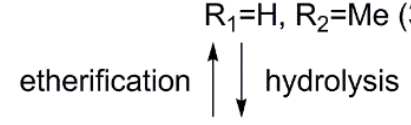

xanthone<smiles>COc1cc(O)c2c(=O)c3c(O)cc(CO)cc3oc2c1</smiles>

wentiquinone $\mathrm{C}$ (2, revised)

Figure 1. Two possible structures for wentiquinone $\mathrm{C}(\mathbf{1}$ and $\mathbf{2})$ and their characteristic ${ }^{13} \mathrm{C}$ NMR data assignments (in DMSO- $d_{6}$ ) as well as the reference compound 3.

\section{Results and Discussion}

The different ways of cyclization led to two possible assignments for the structure of wentiquinone C: one contained a seven-membered lactone (anthraquinone derivative, 1), and another possessed a six-membered ether ring instead (xanthone analog, 2), which having free carboxyl group (Figure 1). The ${ }^{13} \mathrm{C}$ NMR chemical shifts were seemingly reasonable for both assignments, except that in the case of 1 , the resonance assigned for the oxygenated quaternary carbon (C-10) at $\delta_{C} 168.9$ was more downfielded than its usual value (around $\delta_{C}$ 162.0) [4] (Figure 1). The minor distinction implicated an incorrect assignment might be made during the structure elucidation of wentiquinone $C$ [1].

Herein, a methylation method, which applied to demonstrate the authentic structure of wentiquinone $C$, was established inspired by the struactually related analogue (3) (Figure 2). Two crucial methoxy groups in 3 were found to have different ${ }^{13} \mathrm{C}$ NMR shifts, indicating that they are in different chemical environment. One of them is an aromatic methoxy group $\left(\delta_{C} 56.3\right)$, and another is a methyl ester $\left(\delta_{C}\right.$ 53.2). A literature survey indicated the interesting distinction for the chemical shifts of aromatic methoxy and methyl ester groups [5-10] (Figure 2), which supported the undoubted difference in chemical shifts between the two types of methoxy groups. That is, in the ${ }^{13} \mathrm{C}$ NMR spectrum the chemical shifts for aromatic methoxy groups are always bigger than $\delta_{C} 55.0$, while those for methyl esters are usually smaller than $\delta_{C} 55.0$. Thus, unlike wentiquinone $C$, the structure of 3 was unambiguous because of the existence of the methyl ester $\left(\delta_{C} 53.2\right)$, which revealed that the carboxyl had not participate in the cyclization. Similarly, it would be achievable to determine the structure of wentiquinone $C$ by analyzing the shifts of methoxy groups after methylation for carboxyl 
or aromatic hydroxyl groups, and then the assignment of the intramolecular ring could be confirmed accordingly: for the case of structure 1, there should be three aromatic methoxy groups resonating at $\delta_{C}>55$ after methylation, while with respect to structure 2 , one methyl ester resonating at $\delta_{C}<55$ and two aromatic methoxy group resonating at $\delta_{C}>55$ should be observed (Scheme 1).<smiles>COc1cc(C(=O)O)c2c(=O)c3c(O)cc(C)cc3oc2c1</smiles>

$3\left(\mathrm{CDCl}_{3}\right)[2]$<smiles>COc1cc(C(=O)O[Na])c2c([N+](=O)[O-])cc3ccccc3c2c1OC</smiles>

$4\left(\mathrm{CD}_{3} \mathrm{OD}\right)[5]$<smiles>COc1cc(/C=C/C(=O)c2ccccc2O)cc(OC)c1OC</smiles>

5, crotaoprostrin $\left(\mathrm{CDCl}_{3}\right)[6]$<smiles>COCc1c(OC)cc2c(c1OC)C(=O)c1ccccc1C2=O</smiles>

$6\left(\mathrm{CDCl}_{3}\right)[7]$<smiles>COc1ccc(CC2OC(=O)c3c(O)cc(OC)cc32)cc1</smiles><smiles>COc1cc2c(cc1OC)C1(CCC(O)CC1)C1CCN2CC1</smiles><smiles>COc1cc(C(=O)O[Na])c(Oc2c(O)cc(C)cc2C(=O)O[Na])c(C(=O)O[Na])c1Cl</smiles><smiles>COc1cc(C(C)=O)c2c(=O)c3c(O)cc(CO)cc3oc2c1</smiles>

7, $\left(\mathrm{CD}_{3} \mathrm{OD}\right)[8]$

8, (+)-erythravine $\left(\mathrm{CDCl}_{3}\right)[9]$

9, pestalotether $\mathrm{A}\left(\mathrm{CDCl}_{3}\right)[10]$

10, pestaloxanthone $\left(\mathrm{CDCl}_{3}\right)[10]$

Figure $2 .{ }^{13} \mathrm{C}$ NMR chemical shifts for methoxy groups of compound 3 and some previously reported natural products with aromatic methoxy groups and/or methyl esters.<smiles>COc1cc(O)c2c(=O)c3c(O)cc(CO)cc3oc(=O)c2c1</smiles><smiles>COc1cc(OC)c2c(=O)c3c(OC)cc(CO)cc3oc(=O)c2c1</smiles><smiles>COc1cc(C(=O)O)c2c(=O)c3c(O)cc(CO)cc3oc2c1</smiles><smiles>CNCCNC(C)(C)C</smiles><smiles>COC(=O)c1cc(OC)cc2oc3cc(CO)cc(OC)c3c(=O)c12</smiles>

2

Scheme 1. Synthesis of compound 2a.

Methylation of wentiquinone $\mathrm{C}$ was achieved by treatment of the compound with $\mathrm{CH}_{3} \mathrm{I}$ in anhydrous DMF with the presence of $\mathrm{NaH}$ for $45 \mathrm{~min}$ [11]. The major product $\mathbf{2 a}$ was obtained as yellowish amorphous powder in $92 \%$ yield (Figure 3). Its molecular formula was determined to be $\mathrm{C}_{18} \mathrm{H}_{16} \mathrm{O}_{7}$ by HRESIMS $\left(\mathrm{m} / z 345.0964[\mathrm{M}+\mathrm{H}]^{+}\right.$, calcd for $\left.\mathrm{C}_{18} \mathrm{H}_{17} \mathrm{O}_{7}{ }^{+}, 345.0969\right)$, with 28 unit $\left(\mathrm{C}_{2} \mathrm{H}_{4}\right)$ more than that of wentiquinone $\mathrm{C}$. The differences in the 1D NMR data between 2a and wentiquinone $C$ were that signals for two more methoxy groups at $\delta_{\mathrm{C} / \mathrm{H}} 52.4 / 3.85(\mathrm{C} / \mathrm{H}-17)$ and 56.1/3.88 $(\mathrm{C} / \mathrm{H}-18)$ were detected in $\mathbf{2 a}$ (Figure 4 ), while the exchangeable proton of a phenolic hydroxyl group $\left(\delta_{\mathrm{H}} 12.41\right)$ in wentiquinone $C$ disappeared in the ${ }^{1} \mathrm{H}$ NMR spectrum of 2a. As mentioned earlier, $\mathrm{C}-17$ was observed at $\delta_{C} 52.4$ and could be confirmed as a methyl ester, while C-18 was detected at $\delta_{C} 56.1$ and should be an aromatic methoxy group (Figure 4). Therefore, it could be deduced that there is a carboxyl group in wentiquinone $C$, whose structure should be related to xanthone (2) rather than anthraquinone (1). This deduction was verified by the key HMBC correlations (Figure 4) from H-17 to C-14 and from $\mathrm{H}-18$ to $\mathrm{C}-1$. 


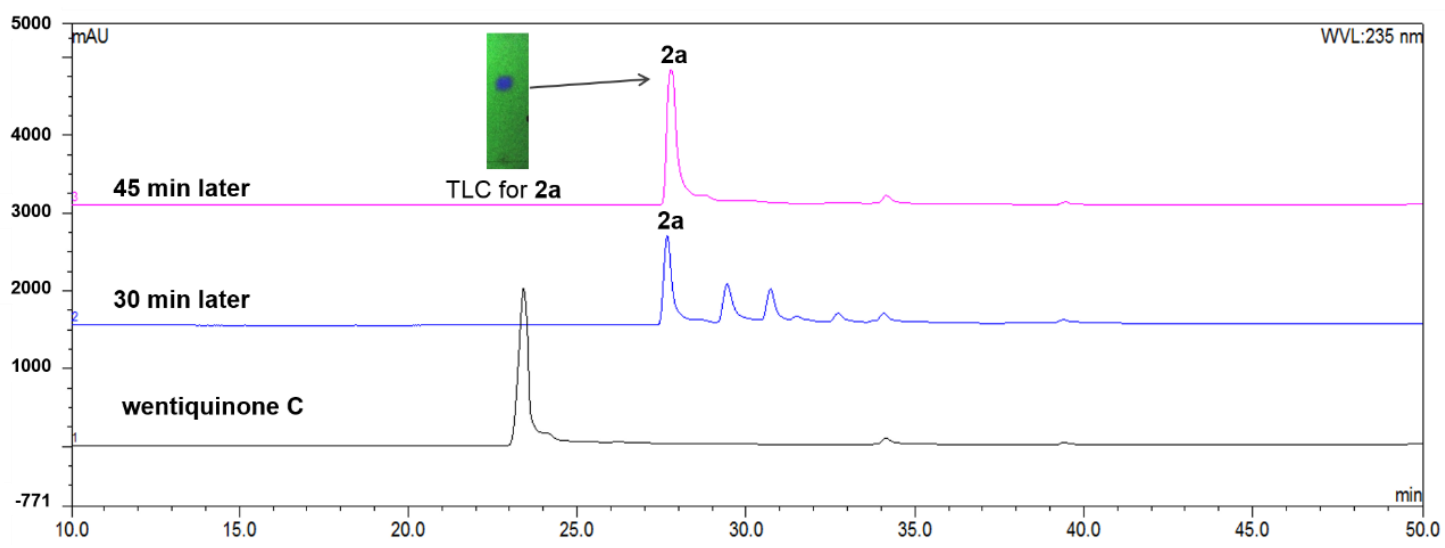

Figure 3. HPLC profiles for wentiquinone $C$ and the reaction products at 30 and $45 \mathrm{~min}$. Gradient: 0-5 min, 10\% methanol in water; 6-35 min, gradient from $10 \%$ methanol in water to $100 \%$ methanol; $35-45 \mathrm{~min}, 100 \%$ methanol; $45-60 \mathrm{~min}$, gradient from $100 \%$ methanol to $10 \%$ methanol in water. TLC developing solvent: $\mathrm{CH}_{2} \mathrm{Cl}_{2}: \mathrm{MeOH}=10: 1$.

$2 \mathbf{a}$
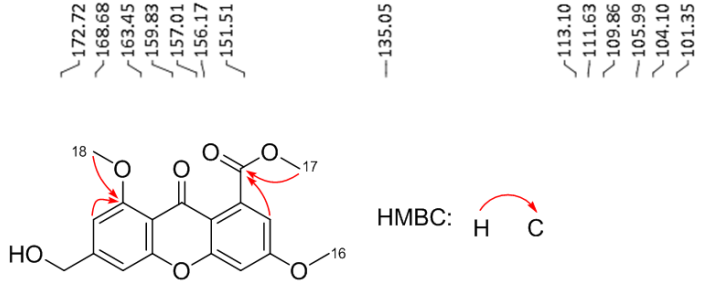

HMBC: $\overparen{H C}$

2a

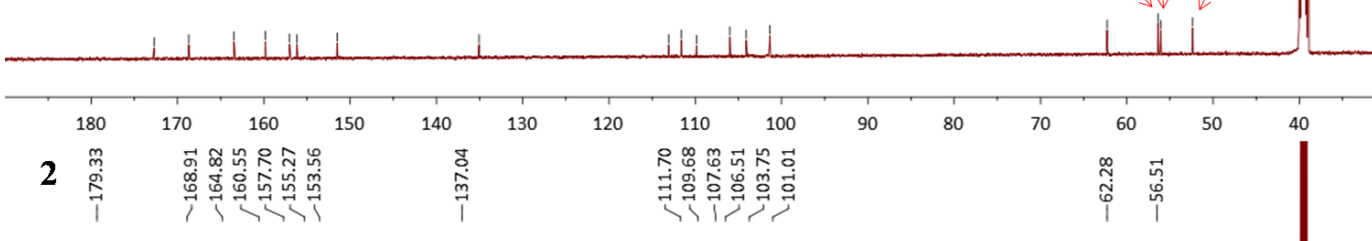

$\mathrm{OH}$ O $\mathrm{O}_{\mathcal{O}}$
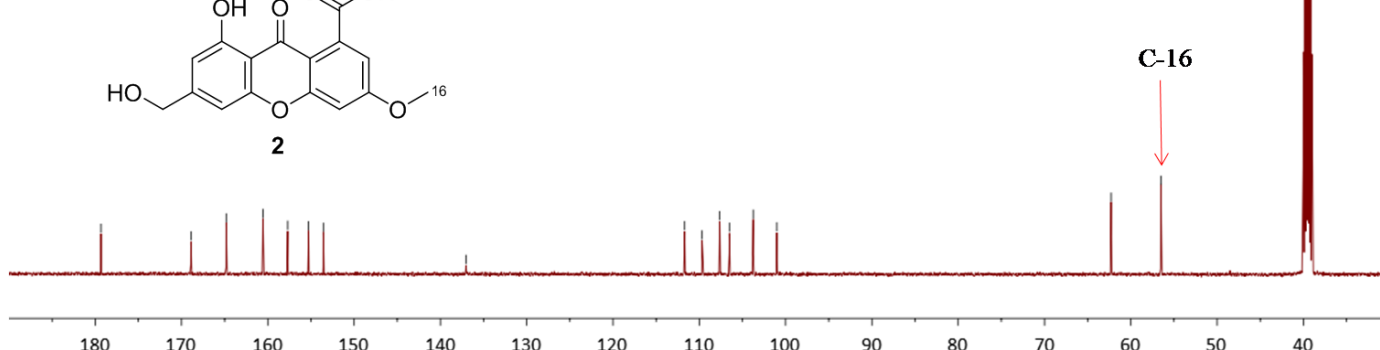

Figure 4. Comparison for ${ }^{13} \mathrm{C}$ NMR spectra between compounds $\mathbf{2 a}$ and $\mathbf{2}$ in DMSO- $d_{6}$.

Slow evaporation of the solvents ( $\left.\mathrm{MeOH}: \mathrm{CHCl}_{3}=1: 1\right)$ by keeping the sample of wentiquinone $\mathrm{C}$ in a refrigerator for one month yielded quality crystals suitable for X-ray crystallographic analysis, which unambiguously confirmed its structure (2) as shown in Figure 5. Thus, the structure of wentiquinone C should be revised to 2 .

The results from a literature survey revealed that, besides wentiquinone $C$, the structures of several other noteworthy molecules of seco-anthraquinone class (Figure 6) need to be revisited, and the method established in this paper could be applied to the structural re-examining or revision for these compounds. For instance, janthinone (11) was originally reported as a seco-anthraquinones in 2005 [12], the structure of which has been revised to a xanthone by another group on the basis of X-ray crystallographic analysis [13]. The structures of some other natural products, such as wentiquinones A and B (12 and 13), CT-1 (14), and compounds 15-18, which were initially assigned the structures as 
seco-anthraquinones [14-18], are likely incorrectly assigned and their structures should be reassessed. Compounds 19 and 20 [19,20], which were considered being seco-anthraquinones, are also required to be re-checked carefully.

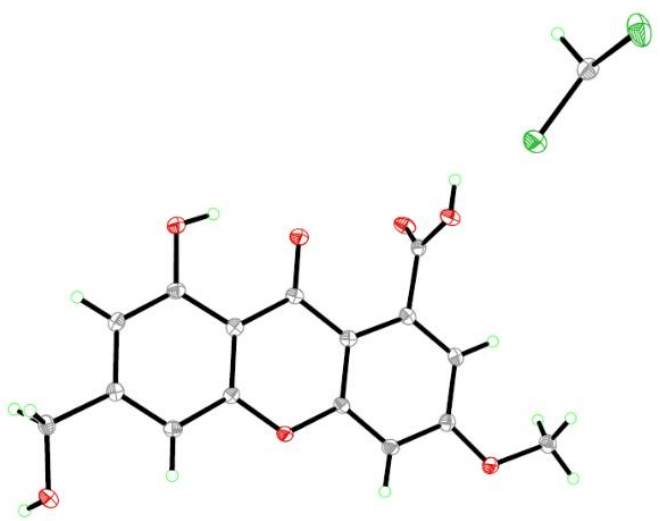

Figure 5. X-ray crystallographic structure of wentiquinone $\mathrm{C}$ (Note: The inclusive of $\mathrm{CHCl}_{3}$ was detected in the $\mathrm{X}$-ray structure of wentiquinone $\mathrm{C}$ ).
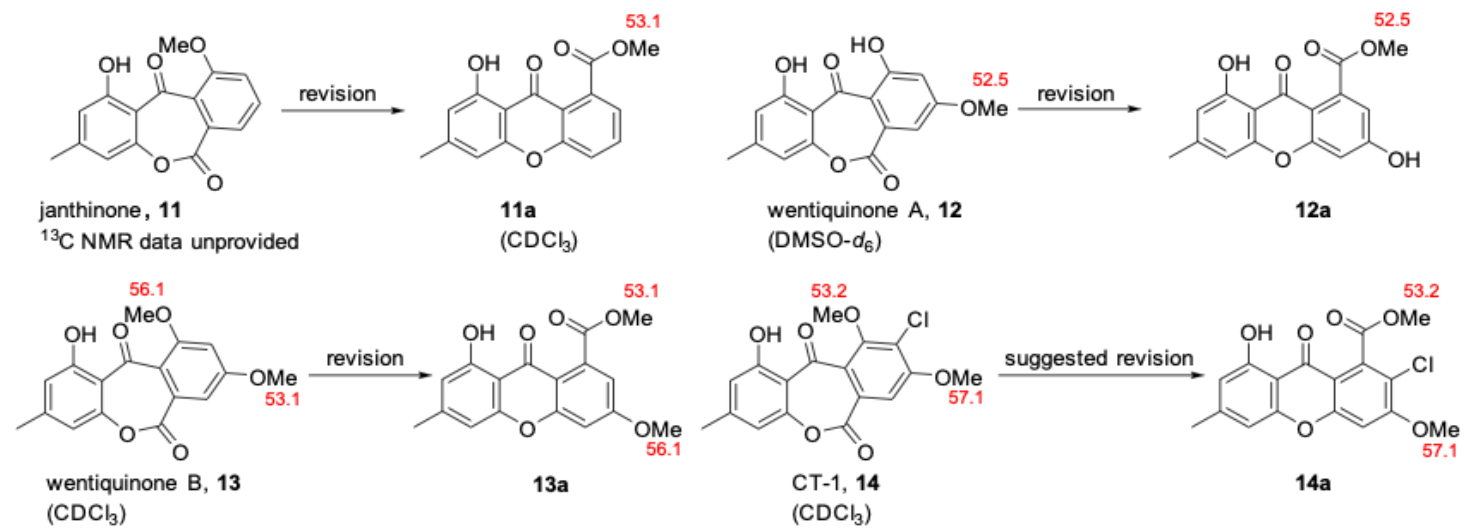<smiles>O=c1c2cccc(O)c2c(=O)oc2cc(CO)cc(O)c12</smiles>

15

(DMSO- $d_{6}$ )<smiles>O=c1oc2c(Cl)c(CO)c(Cl)c(O)c2c(=O)c2c(O)ccc(O)c12</smiles>

17

(DMSO- $\left.d_{6}\right)$<smiles></smiles>

19 (DMSO- $d_{6}$ )

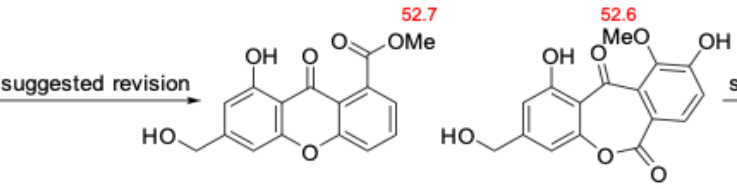

$15 a$

16

(DMSO-d ${ }_{6}$ )

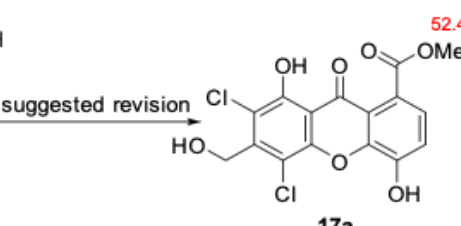

$17 a$

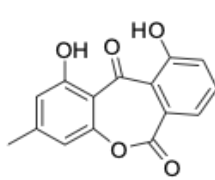

alternaphenol B, 20

Figure 6. Assigned structures of seco-anthraquinones requiring reassessment as xanthones. 


\section{Materials and Methods}

\subsection{General Experimental Procedures}

Melting points were determined with an SGW X-4 micromeltingpoint apparatus (Shanghai Shenguang Instrument Co. Ltd, Shanghai, China). UV spectra were measured on a PuXi TU-1810 UV-visible spectrophotometer (Shanghai Lengguang Technology Co. Ltd., Shanghai, China). 1D and 2D NMR spectra were obtained at 500 and $125 \mathrm{MHz}$ for ${ }^{1} \mathrm{H}$ and ${ }^{13} \mathrm{C}$, respectively, on a Bruker Avance $500 \mathrm{MHz}$ spectrometer (Bruker Biospin Group, Karlsruhe, Germany) with tetramethyl silane (TMS) as an internal standard. Mass spectra were generated on a VG Autospec 3000 (VG Instruments, London, UK) or an API QSTAR Pulsar 1 mass spectrometer (Applied Biosystems, Foster, Waltham, MA, USA). Analytical and semipreparative HPLC were performed using a Dionex HPLC system equipped with a P680 pump, an ASI-100 automated sample injector, and a UVD340U multiple wavelength detector controlled by Chromeleon software (version 6.80) (Dionex, Sunnyvale, CA, USA). Commercially available Si gel (200-300 mesh, Qingdao Haiyang Chemical Co., Qingdao, China), Lobar LiChroprep RP-18 (40-63 m, Merck, Darmstadt, Germany), and Sephadex LH-20 (Pharmacia, Pittsburgh, PA, USA) were used for open column chromatography. All solvents were distilled prior to use.

\subsection{Methylation of Wentiquinone $C$}

A suspension of $\mathrm{NaH}(1.0 \mathrm{mg})$ in $1.0 \mathrm{~mL}$ of anhydrous DMF was treated with a solution of wentiquinone $\mathrm{C}(3.0 \mathrm{mg})$ in $3.0 \mathrm{~mL}$ of DMF at $0{ }^{\circ} \mathrm{C}$. The reaction mixture was stirred at $0{ }^{\circ} \mathrm{C}$ for $30 \mathrm{~min}$, and then $\mathrm{CH}_{3} \mathrm{I}(30 \mu \mathrm{L})$ was added. After $45 \mathrm{~min}$, a saturated solution of $\mathrm{NH}_{4} \mathrm{Cl}(10.0 \mathrm{~mL})$ was added to quench the reaction. The product was extracted with EtOAc $(4 \times 10 \mathrm{~mL})$ and purified by HPLC to give $2 \mathrm{a}(3.0 \mathrm{mg}, 92 \%)$.

\subsection{Wentiquinone C (2)}

Yellow crystals; m.p. 287-289 ${ }^{\circ} \mathrm{C}$; UV (MeOH) $\lambda_{\max }(\log \varepsilon) 236$ (4.61), 247 (4.55), 305 (4.28), $354(3.93) \mathrm{nm} ;{ }^{1} \mathrm{H}$ NMR(DMSO- $\left.d_{6}, 500 \mathrm{MHz}\right) \delta 6.75(1 \mathrm{H}, \mathrm{brs}, \mathrm{H}-2), 6.95(1 \mathrm{H}$, brs, H-4), $7.16(1 \mathrm{H}, \mathrm{d}$, $J=2.0 \mathrm{~Hz}, \mathrm{H}-7), 6.93(1 \mathrm{H}, \mathrm{d}, J=2.0 \mathrm{~Hz}, \mathrm{H}-9), 4.59$ (2H, s, H-15), $3.94(3 \mathrm{H}, \mathrm{s}, \mathrm{H}-16), 12.41(1 \mathrm{H}, \mathrm{s}, 1-\mathrm{OH})$; ${ }^{13} \mathrm{C}$ NMR (DMSO- $\left.d_{6}, 125 \mathrm{MHz}\right) \delta 160.6$ (C-1, C), 107.6 (C-2, CH), 153.6 (C-3, C), 103.8 (C-4, CH), 155.3 (C-5, C), 157.7 (C-6, C), 100.8 (C-7, CH), 164.8 (C-8, C), 111.7 (C-9, CH), 137.0 (C-10, C), 109.7 (C-11, C), $106.5(\mathrm{C}-12, \mathrm{C}), 179.4(\mathrm{C}-13, \mathrm{C}), 168.9(\mathrm{C}-14, \mathrm{C}), 62.3\left(\mathrm{C}-15, \mathrm{CH}_{2}\right), 56.5\left(\mathrm{C}-16, \mathrm{CH}_{3}\right)$. HRESIMS m/z $317.0639\left([\mathrm{M}+\mathrm{H}]^{+}\right)$(calculated for $\left.\mathrm{C}_{16} \mathrm{H}_{13} \mathrm{O}_{7}{ }^{+}, 317.0656\right)$.

\subsection{Compound $2 \mathrm{a}$}

Yellow amorphous powder; UV (MeOH) $\lambda_{\max }(\log \varepsilon) 235$ (4.53), 248 (4.45), 303 (4.15), 350 (3.86) $\mathrm{nm} ;{ }^{1} \mathrm{H}$ NMR (DMSO- $\left.d_{6}, 500 \mathrm{MHz}\right) \delta 6.94(1 \mathrm{H}, \mathrm{s}, \mathrm{H}-2), 7.06(1 \mathrm{H}, \mathrm{s}, \mathrm{H}-4), 7.17(1 \mathrm{H}, \mathrm{s}, \mathrm{H}-7), 6.94(1 \mathrm{H}, \mathrm{s}$, H-9), $4.63(2 \mathrm{H}, \mathrm{d}, J=5.6 \mathrm{~Hz}, \mathrm{H}-15), 3.92(3 \mathrm{H}, \mathrm{s}, \mathrm{H}-16), 3.85$ (3H, s, H-17), 3.88 (3H, s, H-18), $5.54(1 \mathrm{H}$, brs, $15-\mathrm{OH}) ;{ }^{13} \mathrm{C}$ NMR(DMSO- $\left.d_{6}, 125 \mathrm{MHz}\right) \delta 159.8$ (C-1, C), 104.1 (C-2, CH), 151.5 (C-3, C), 106.0 (C-4, $\mathrm{CH}), 157.0$ (C-5, C), 156.2 (C-6, C), 101.4 (C-7, CH), 163.4 (C-8, C), 111.6 (C-9, CH), 135.0 (C-10, C), 113.1 (C-11, C), 109.9 (C-12, C), 172.7 (C-13, C), 168.7 (C-14, C), $62.3\left(\mathrm{C}-15, \mathrm{CH}_{2}\right), 56.4\left(\mathrm{C}-16, \mathrm{CH}_{3}\right), 52.4$ (C-17, $\left.\mathrm{CH}_{3}\right), 56.1\left(\mathrm{C}-18, \mathrm{CH}_{3}\right)$. HRESIMS $\mathrm{m} / z 345.0964\left([\mathrm{M}+\mathrm{H}]^{+}\right)$(calculated for $\left.\mathrm{C}_{18} \mathrm{H}_{17} \mathrm{O}_{7}{ }^{+}, 345.0969\right)$.

\subsection{X-ray Crystallographic Analysis of Wentiquinone C (2)}

All crystallographic data were collected on an Agilent Xcalibur Eos Gemini CCD plate diffractometer equipped with a graphite-monochromatic $\mathrm{Cu} \mathrm{K} \alpha$ radiation $(\lambda=1.54178 \AA)$ at $293(2)$ $K$. The data were corrected for absorption by using the program SADABS [21]. The structure was solved by direct methods with the SHELXTL software package [22]. All nonhydrogen atoms were refined anisotropically. The $\mathrm{H}$ atoms were located by geometrical calculations, and their positions 
and thermal parameters were fixed during the structure refinement. The structure was refined by full-matrix least-squares techniques [23].

\subsection{Crystal Data for Wentiquinone C (2)}

$\mathrm{C}_{32} \mathrm{H}_{24} \mathrm{O}_{14} \cdot \mathrm{CHCl}_{3}, \mathrm{FW}=751.88$, monoclinic space group $\mathrm{C} 2 / \mathrm{c}$, unit cell dimensions $a=12.9467(7)$ $\AA, b=10.9982(8) \AA, c=22.0459(15) \AA, \mathrm{V}=3041.8(3) \AA 33, \alpha=90^{\circ}, \beta=104.302(2)^{\circ}, \gamma=90^{\circ}, \mathrm{Z}=4, d_{\text {calcd }}$ $=1.642 \mathrm{mg} / \mathrm{m} 3$, crystal dimensions $0.42 \mathrm{~mm} \times 0.40 \mathrm{~mm} \times 0.25 \mathrm{~mm}, \mu=3.414 \mathrm{~mm}^{-1}, F(000)=1544$. The 9808 measurements yielded 2675 independent reflections after equivalent data were averaged, and Lorentz and polarization corrections were applied. The final refinement gave $R_{1}=0.0431$ and $w \mathrm{R}_{2}=0.1156[I>2 \sigma(I)]$. Crystallographic data of wentiquinone $C(2)$ have been deposited in the Cambridge Crystallographic Data Centre as CCDC 1406785. The data can be obtained free of charge via http:/ / www.ccdc.cam.ac.uk/data_request/cif (or from the CCDC, 12 Union Road, Cambridge CB21EZ, UK; fax: +44-1223-336-033; e-mail: deposit@ccdc.cam.ac.uk).

\section{Conclusions}

In conclusion, the structure of wentiquinone $\mathrm{C}$ was revised to be 8-hydroxy-6-(hydroxymethyl)-3methoxy-9-oxo-9H-xanthene-1-carboxylic acid (2) by a methylation method and confirmed by an X-ray diffraction study. The characteristic differences between aromatic methoxy group and methyl ester were discussed here based on the literatures data, and the methylation method has proven to be useful to rectify such a misassignment for structurally related compounds.

Author Contributions: X.L. performed the experiments for the isolation, structure elucidation, and synthesis reactions, and prepared the manuscript; X.-M.L. performed the 1D and 2D NMR experiments; B.-G.W. supervised the research work and revised the manuscript.

Funding: This work was financially supported by the Natural Science Foundation of China (31330009 and 41706182) and by Shandong Provincial Natural Science Foundation (ZR2017BB073).

Acknowledgments: The authors appreciate Weaam Ebrahim at Institute of Pharmaceutical Biology and Biotechnology, Heinrich-Heine Universität Düsseldorf, for drawing our attention to the incorrect assignment of the chemical structure of wentiquinone C. Bin-Gui Wang acknowledges the support of Taishan Scholar Project from Shandong Province.

Conflicts of Interest: The authors declare no conflict of interest.

\section{References}

1. Li, X.; Li, X.M.; Xu, G.M.; Li, C.S.; Wang, B.G. Antioxidant metabolites from marine alga-derived fungus Aspergillus wentii EN-48. Phytochem. Lett. 2014, 7, 120-123. [CrossRef]

2. Hamasaki, T.; Kimura, Y. Isolation and structures of four new metabolites from Aspergillus wentii. Agric. Biol. Chem. 1983, 47, 163-165. [CrossRef]

3. Abdissa, N.; Heydenreich, M.; Midiwo, J.O.; Ndakala, A.; Majer, Z.; Neumann, B.; Stammler, H.; Sewald, N.; Yenesew, A. A xanthone and a phenylanthraquinone from the roots of Bulbine frutescens, and the revision of six seco-anthraquinones into xanthones. Phytochem. Lett. 2014, 9, 67-73. [CrossRef]

4. Hein, S.M.; Gloer, J.B.; Koster, B.; Malloch, D. Arugosin F: A new antifungal metabolite from the coprophilous fungus Ascodesmis sphaerospora. J. Nat. Prod. 1998, 61, 1566-1567. [CrossRef] [PubMed]

5. Mizuno, M.; Oka, M.; Iinuma, M.; Tanaka, T. An aristolochic acid derivative of Aristolochia liukiuensis. J. Nat. Prod. 1990, 53, 179-181. [CrossRef]

6. Krohn, K.; Steingröver, K.; Srinivasa Rao, M. Isolation and synthesis of chalcones with different degrees of saturation. Phytochemistry 2002, 61, 931-936. [CrossRef]

7. Chiriboga, X.; Gilardoni, G.; Magnaghi, I.; Finzi, P.V.; Zanoni, G.; Vidari, G. New anthracene derivatives from Coussarea macrophylla. J. Nat. Prod. 2003, 66, 905-909. [CrossRef] [PubMed]

8. Zidorn, C.; Grass, S.; Ellmerer, E.P.; Ongania, K.; Stuppner, H. Stilbenoids from Tragopogon orientalis. Phytochemistry 2006, 67, 2182-2188. [CrossRef] [PubMed]

9. Flausino, O.; Santos, L.A.; Verli, H.; Pereira, A.M.; Bolzani, V.S.; Nunes-de-Souza, R.L. Anxiolytic effects of erythrinian alkaloids from Erythrina mulungu. J. Nat. Prod. 2007, 70, 48-53. [CrossRef] [PubMed] 
10. Klaiklay, S.; Rukachaisirikul, V.; Tadpetch, K.; Sukpondma, Y.; Phongpaichit, S.; Buatong, J.; Sakayaroj, J. Chlorinated chromone and diphenyl ether derivatives from the mangrove-derived fungus Pestalotiopsis $\mathrm{sp}$. PSU-MA69. Tetrahedron 2012, 68, 2299-2305. [CrossRef]

11. Fu, P.; Wang, S.X.; Hong, K.; Li, X.; Liu, P.P.; Wang, Y.; Zhu, W.M. Cytotoxic bipyridines from the marine-derived actinomycete Actinoalloteichus cyanogriseus WH1-2216-6. J. Nat. Prod. 2011, 74, 1751-1756. [CrossRef] [PubMed]

12. Marinho, A.M.R.; Rodrigues-Filho, E.; Moitinho, M.L.R.; Santos, L.S. Biologically active polyketides produced by Penicillium janthinellum isolated as an endophytic fungus from fruits of Melia azedarach. J. Braz. Chem. Soc. 2005, 16, 280-283. [CrossRef]

13. Shao, C.; Wang, C.; Wei, M.; Gu, Y.; Xia, X.; She, Z.; Lin, Y. Structure elucidation of two new xanthone derivatives from the marine fungus Penicillium sp. (ZZF 32\#) from the South China Sea. Magn. Reson. Chem. 2008, 46, 1066-1069.

14. Sun, H.F.; Li, X.M.; Meng, L.H.; Cui, C.M.; Gao, S.S.; Li, C.S.; Wang, B.G. Two new seco-anthraquinone derivatives from the Marine-derived endophytic fungus Aspergillus wentii EN-48. Helv. Chim. Acta 2013, 96, 458-462. [CrossRef]

15. Fujimoto, H.; Inagaki, M.; Satoh, Y.; Yoshida, E.; Yamazaki, M. Monoamine oxidase-inhibitory components from an ascomycete, Coniochaeta tetraspora. Chem. Pharm. Bull. 1996, 44, 1090-1092. [CrossRef]

16. Carvalho, M.R.; de Almeida Barbosa, L.C.; de Queiróz, J.H.; Howarth, O.W. Novel lactones from Aspergillus versicolor. Tetrahedron Lett. 2001, 42, 809-811. [CrossRef]

17. Chunyu, W.X.; Zhao, J.Y.; Ding, Z.G.; Wang, Y.X.; Han, X.L.; Li, M.G.; Wen, M.L. A new dichlorinated aromatic lactone from the tin mine tailings-derived fungus Torula sp. YIM DT 10072. Chem. Nat. Compd. 2018, 54, 432-434. [CrossRef]

18. Guo, Z.; Cheng, F.; Zou, K.; Wang, J.; She, Z.; Lin, Y. Secondary metabolites from the mangrove endophytic fungus Penicillium sp. (SBE-8). Nat. Prod. Commun. 2009, 4, 1481-1483. [PubMed]

19. Pan, J.H.; Deng, J.J.; Chen, Y.G.; Gao, J.P.; Lin, Y.C.; She, Z.G.; Gu, Y.C. New lactone and xanthone derivatives produced by a mangrove endophytic fungus Phoma sp. SK3RW1M from the South China Sea. Helv. Chim. Acta 2010, 93, 1369-1374. [CrossRef]

20. Shen, Y.; Xu, Q.L.; Cheng, P.; Liu, C.L.; Lu, Z.Y.; Li, W.; Wang, T.T.; Lu, Y.H.; Tan, R.X.; Ge, H.M.; et al. Aromatic polyketides from a caterpillar associated Alternaria sp. Tetrahedron Lett. 2017, 58, 3069-3072. [CrossRef]

21. Sheldrick, G.M. SADABS, Software for Empirical Absorption Correction; University of Gottingen: Gottingen, Germany, 1996.

22. Sheldrick, G.M. SHELXTL, Structure Determination Software Programs; Bruker Analytical X-ray System Inc.: Madison, WI, USA, 1997.

23. Sheldrick, G.M. SHELXL-97 and SHELXS-97, Program for X-ray Crystal Structure Solution and Refinement; University of Göttingen: Göttingen, Germany, 1997.

(C) 2018 by the authors. Licensee MDPI, Basel, Switzerland. This article is an open access article distributed under the terms and conditions of the Creative Commons Attribution (CC BY) license (http://creativecommons.org/licenses/by/4.0/). 